\section{'Mountain Honey' Hybrid Grape Tomato and Its Parent NC 6 Grape Breeding Line}

\author{
Dilip R. Panthee ${ }^{\mathbf{1}}$ and Randy G. Gardner \\ Department of Horticultural Science, North Carolina State University, \\ Mountain Horticultural Crops Research and Extension Center (MHCREC), \\ 455 Research Drive, Mills River, NC 28759-3423
}

Additional index words. $b r$ gene, crimson $\left(B c\right.$ or $\left.o g^{c}\right)$ gene, disease resistance, $I-3$ gene, late blight, $P h-2$ gene, $S w-5$ gene, total soluble solids

'Mountain Honey' is a hybrid grape tomato (Solanum lycopersicum L.) resulting from the cross of NC 4 grape $\times$ NC 6 grape. It is heterozygous-resistant to fusarium wilt race 3 [Fusarium oxysporum f.sp. lycopersici (Sacc.) Snyd. and Hans.], late blight (Ph-2 gene) (Phytophthora infestans Montagne, Bary), and Tomato spotted wilt virus (TSWV) ( $S w$-5 gene). It has a compact indeterminate plant with short internodes conferred by the brachytic $(b r)$ gene and has dark red fruit with high total soluble solids.

\section{Origin}

'Mountain Honey' $F_{1}$ hybrid grape tomato resulted from a tomato breeding effort initiated in 2003 to develop a superior hybrid grape tomato similar in plant and fruit type to 'Smarty' but with the additions of late blight, fusarium wilt race 3 , and TSWV resistances. The resultant hybrid, 'Mountain Honey', first crossed in the fall of 2009, was tested as NC 10242 in replicated and observational trials at the Mountain Horticultural Crops Research and Extension Center (MHCREC), Mills River, $\mathrm{NC}$, in 2010-12 and was widely tested in grower plantings in western North Carolina (NC) and in the coastal area of South Carolina (SC).

NC 4 grape shown in the top of the pedigree in Figure 1 resulted from a breeding effort initiated in 2002 to add resistance genes for TSWV $(S w-5)$ and fusarium wilt race 3 (I-3) along with other useful traits into a compact, indeterminate growth habit breeding line with short internodes conferred by the brachytic $(b r)$ gene. It was described in conjunction with its use as a parent in the 'Mountain Vineyard' $F_{1}$ hybrid grape tomato (Panthee and Gardner, 2013). NC 6 grape resulted from breeding to develop a late blight-resistant, compact, indeterminate, brachytic growth habit grape tomato breeding line that could be used

Received for publication 10 Apr. 2013. Accepted for publication 1 Aug. 2013.

The tomato breeding program of North Carolina State University is supported by the North Carolina Tomato Growers Association and the Hatch project of the USDA.

${ }^{1}$ To whom reprint requests should be addressed; e-mail Dilip_panthee@ncsu.edu. as a parent in a 'Smarty'-type grape tomato $\mathrm{F}_{1}$ hybrid. 'Smarty', resulting from the cross of NC 3 grape $\times$ NC 2 grape (Gardner and Panthee, 2010), is a highly successful cultivar that is widely grown. NC 2 grape was used extensively as the source of desirable grape tomato fruit and plant traits in developing NC 6 grape.

NC 2 grape was crossed with 03220 (x)20, a large-fruited, early blight/late blightresistant tomato line having the $P h-2$ and $P h-3$ genes combined for late blight resistance (Fig. 1). The resultant 0463 hybrid was then crossed with 9722 (x)-18, an early blight/late blight-resistant $\mathrm{F}_{2}$ selection derived from backcrossing to introgress the $P h-3$ gene for late blight resistance from $\mathrm{L}$ 3707 into the early blight-resistant line 215 E-1 (93). The plants from this cross were selected in the $F_{2}$ generation in the field for late blight resistance in 2005 and then grown in the greenhouse in the $F_{3}$ generation and identified as late blight-resistant individuals using a detached leaf inoculation test. The resultant $05108(\mathrm{x})-2-166 \mathrm{~F}_{3}$ selection was crossed to 051 (x)-18 gsms, an $\mathrm{F}_{2}$ selection of a brachytic, indeterminate, crimson ( $B C$ or $o g^{c}$ ) gene grape tomato line to produce the $\mathrm{F}_{1}$ hybrid 0674 . The 0674 hybrid was evaluated in the field for late blight resistance in 2006 , and a single $\mathrm{F}_{1}$ plant designated as $0674-2 \mathrm{~W}$ with desirable horticultural traits and a high level of late blight resistance was selected. In the $F_{2}$ generation, a single plant designated as 0674-2W(x)-1W was selected. This selection is a very large grape-type tomato with firm, deep red, high sugar fruit that has shown good resistance to early blight and septoria leaf spot in addition to late blight.

NC 2 grape (Gardner and Panthee, 2010) was crossed in the greenhouse in the fall of 2003 to the early blight/late blight $(P h-2+$ $P h-3$ genes combined) $03220(\mathrm{x})-11$ largefruited line to produce the $\mathrm{F}_{1}$ hybrid 0464 . The 0464 hybrid was crossed with 9722 (x)-18, and the resultant hybrid, 05109, was grown in the field in the $F_{2}$ generation in 2005 and selected for late blight resistance. The $\mathrm{F}_{3}$ generation was grown in the greenhouse, and 05109(x)-1-198, a high sugar cherry tomato selection was identified as late blight-resistant by a detached leaf inoculation technique. 05109 (x)-1-198 was crossed with the $F_{1}$ hybrid 0661 to produce the $\mathrm{F}_{1}$ hybrid designated as 06160 . Hybrid 0661 was the result of a cross between 051 (x)-18 gsms, a brachytic, crimson, indeterminate grape tomato line, and $\mathrm{CB} 25(\mathrm{x})-18-3$, an $\mathrm{F}_{3}$ generation indeterminate, brachytic, high sugar cherry tomato line resulting from selfing the Clause Seed Co. experimental $\mathrm{F}_{1}$ hybrid cherry tomato $\mathrm{CB}$ 25 ( $\mathrm{F}_{1}$ of Clause proprietary cherry tomato line $\times \mathrm{NC} 1$ grape tomato). The $\mathrm{F}_{2}$ generation derived from a single $F_{1}$ plant, 06160-2A, was grown in the field in 2007 to produce the outstanding crimson, compact, indeterminate, brachytic gene grape tomato selection $06160-2 \mathrm{~A}(\mathrm{x})-2$. The $\mathrm{F}_{3}$ generation from this selection was grown in the greenhouse in Fall 2007 and a single plant $F_{3}$ selection, 06160-2A(x)-2-1, was crossed with 0674$2 \mathrm{~W}(\mathrm{x})-1 \mathrm{~W}$ to produce the $\mathrm{F}_{1}$ hybrid 08135 .

An $F_{2}$ population of 200 plants derived from selfing 08135 was grown in 2008 in a field planting at the Mountain Research Station, Waynesville, NC. Late blight was not present in this planting because of very dry weather conditions so selection was made for plants with a compact, indeterminate, brachytic plant type in combination with the most desirable fruit traits for grape tomatoes. These selections were grown in the $\mathrm{F}_{3}$ generation in the greenhouse in the fall of 2008 and tested for late blight resistance using a detached leaf test. The $\mathrm{F}_{3}$ selection 08135 (x)-8W-15 was identified as resistant to late blight and had desired horticultural traits. The $\mathrm{F}_{4}$ generation from $08135(\mathrm{x})-8 \mathrm{~W}-15$ was grown in the field in 2009 and evaluated for late blight resistance. The $\mathrm{F}_{4}$ line was homozygous-resistant for late blight, and 20 outstanding plants were selected for further evaluation. $\mathrm{F}_{5}$ generation plants were grown in the greenhouse in fall/winter of 2009-10 and evaluated for fruit quality, total soluble solids (TSS), and plant type. NC08135(X)8W-15-16-64 was selected for its outstanding combination of desirable plant and fruit traits and high TSS content $(8.3 \%)$ and is being released as NC 6 grape tomato.

When NC 6 grape was evaluated for late blight resistance using a field isolate in the greenhouse in 2012, it was susceptible to the strain of late blight used for inoculation. Testing with molecular markers linked to the $P h-2$ and $P h-3$ genes for late blight resistance showed that NC 6 grape is homozygous for the $P h-2$ gene for resistance but lacks the $P h-3$ gene. Additional breeding is underway to combine the $P h-2$ and $P h-3$ genes in a similar line to improve durability of late blight resistance.

\section{Description}

'Mountain Honey' has a vigorous, indeterminate growth habit with short internodes conferred by the brachytic (br) gene. Plants are slightly shorter than those of 'Smarty' with lighter green foliage color that is slightly less dense than that of 'Smarty'. It has uniform green color of immature fruit $(u$ gene) and averages $\approx 11 \mathrm{~g}$ per fruit. Fruit pedicels are jointed. Ripe fruit are dark red in 


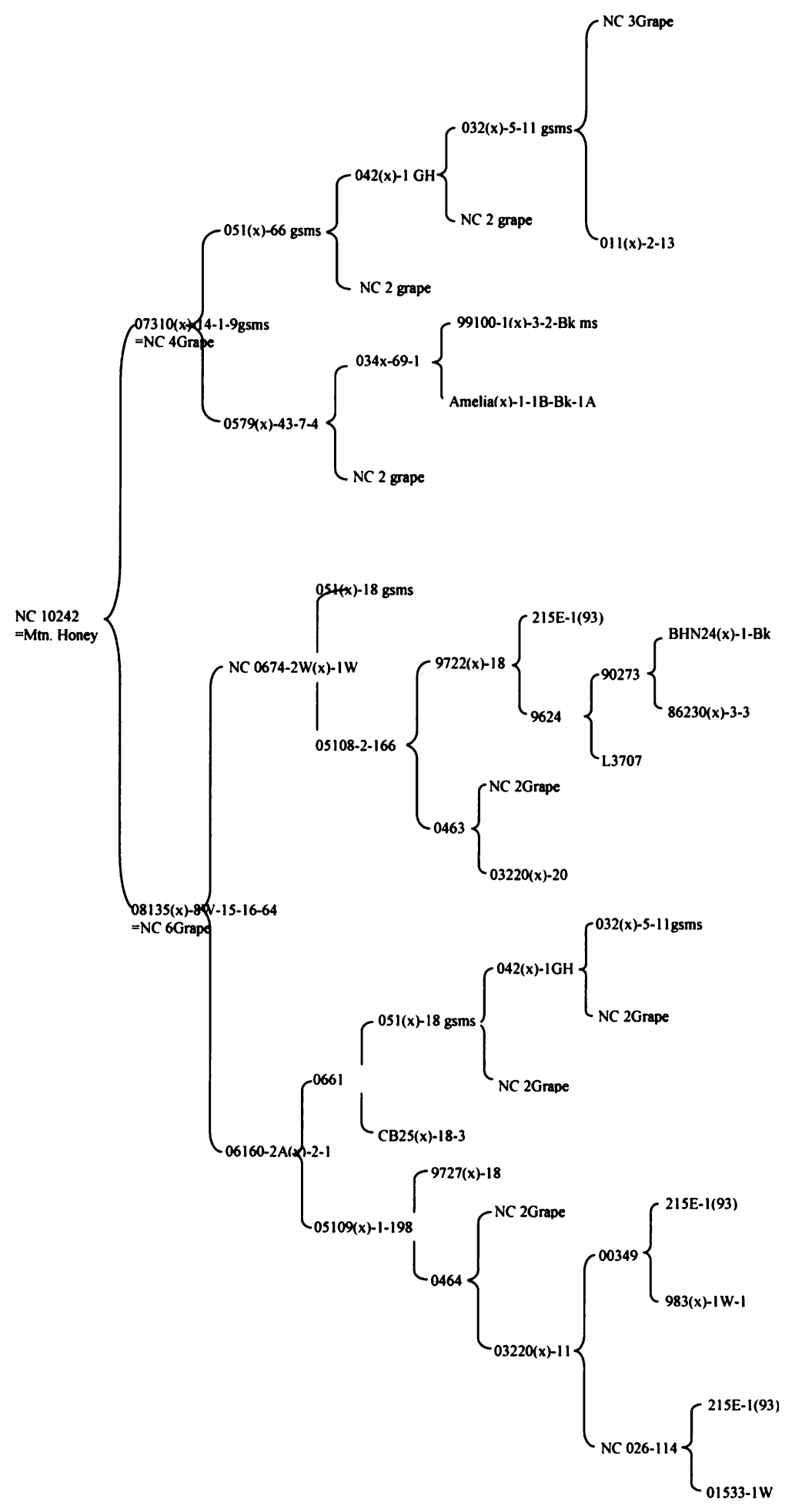

Fig. 1. Pedigree of 'Mountain Honey' hybrid grape tomato and its parent, NC 6 grape tomato. NC 4 grape is described elsewhere.

color, long and ovate in shape, and are very sweet with a crisp texture. When averaged over four trials with three replications each at MHCREC in field trials in the summer seasons of 2010-12, 'Mountain Honey' was significantly higher than 'Smarty' in total yield, marketable yield, and percent marketable yield and had equivalent fruit size to 'Smarty' (Table 1). Average TSS ( ${ }^{\circ}$ Brix) of 'Mountain Honey' was slightly lower than 'Smarty' when six fruit per replication were
In growers' plantings in coastal SC, where TSWV was prevalent, 'Mountain Honey' was free of virus symptoms, whereas 'Smarty' was severely affected by the disease. In a greenhouse seedling screen in 2012, 'Mountain Honey' lacked resistance to late blight as a result of the field isolate used for screening having overcome the $\mathrm{Ph}-2$ gene in heterozygous condition in the hybrid (Table 1). Presence of the $I-3$ and $S w-5$ genes (Panthee and Ibrahem, 2013) in heterozygous condition for resistance to fusarium wilt race 3 and TSWV, respectively, were verified by molecular markers tightly linked to the resistance genes (Fig. 2). A high level of resistance to fusarium wilt race 3 was verified for 'Mountain Honey' in a seedling inoculation screen in a growth chamber.

NC 6 grape tomato breeding line has a vigorous plant with a compact indeterminate growth habit with short internodes conditioned by the brachytic $(b r)$ gene. Foliage is lighter green than that of other grape tomato lines in the North Carolina tomato breeding program and slightly less dense. Fruit of NC 6 grape tomato average $\approx 16 \mathrm{~g}$. They develop a deep red color, are crisp in texture, and are firm in the fully ripened stage. Immature fruit have a glossy, uniform light green color $(u$ gene). Fruit pedicels are jointed with a tendency for the pedicels to remain attached to the fruit during harvest. The fruit are elongated and ovate in shape and have good resistance to fruit cracking and bursting despite high TSS ( ${ }^{\circ}$ Brix) levels. NC 6 grape is the first known breeding line of grape tomato with the $P h-2$ gene for late blight resistance. It may have other resistance genes such as the $V e$ gene for resistance to verticillium wilt and the $I$ genes for resistance to races 1 of fusarium wilt. They were not found to have $I$ 2 conferring resistance to race 2 of fusarium wilt (data not shown). NC 6 grape was not evaluated in replicated trials for yield or other characteristics because it is intended for use as a parent in producing $F_{1}$ hybrids only and not as a cultivar for fruit production. However, it has shown heavy fruit set in observational plots with potential for high yield.

\section{Use}

'Mountain Honey' provides growers in $\mathrm{NC}$ and other regions with similar growing conditions a high-yielding, fusarium wilt race 3, late blight, and TSWV-resistant grape tomato cultivar with improved color and fruit size comparable to 'Smarty'. Because the $P h-2$ gene offers protection against limited strains of late blight and is often overcome under severe late blight conditions, the late blight resistance will likely not hold up in seasons with severe late blight pressure. NC 6 grape provides tomato breeders with the $P h-2$ gene for late blight resistance, superior fruit quality, high yield potential, and desirable plant traits and should be useful for further breeding and as a parent in other $\mathrm{F}_{1}$ hybrids. 
Table 1. Average performance of 'Mountain Honey' compared with the control hybrid grape tomato 'Smarty' (2010-12). ${ }^{\mathrm{z}}$

\begin{tabular}{|c|c|c|c|c|c|c|}
\hline Genotype & $\begin{array}{l}\text { Total yield } \\
\left(\mathrm{t} \cdot \mathrm{ha}^{-1}\right)\end{array}$ & $\begin{array}{l}\text { Marketable } \\
\text { yield }\left(\mathrm{t} \cdot \mathrm{ha}^{-1}\right)\end{array}$ & $\begin{array}{c}\text { Marketable } \\
(\%)\end{array}$ & $\begin{array}{l}\text { Fruit } \\
\text { wt }(g)\end{array}$ & $\begin{array}{l}\text { Total soluble } \\
\text { solids }(\%)^{y}\end{array}$ & $\begin{array}{l}\text { Late blight } \\
\text { score }^{\mathrm{x}}\end{array}$ \\
\hline Smarty & 43.7 & 41.0 & 91.7 & 9.8 & 7.5 & 4.5 \\
\hline $\operatorname{LSD}_{(0.05)}$ & 3.4 & 3.4 & 1.2 & NS & 0.4 & NS \\
\hline
\end{tabular}

${ }^{\mathrm{z}}$ Data are an average of early and late replicated trials in 2010, early replicated trial of 2011, and late replicated trial of 2012 at the Mountain Horticultural Crops Research Station, Mills River, NC. Least square means (LSMeans) and least significant difference (LSD) values presented in the table were obtained from analysis of variance (performed using SAS software (SAS Institute Inc., 2007).

${ }^{\mathrm{y}} \mathrm{TSS}$ was measured only in 2010 and 2011.

${ }^{x}$ Late blight test conducted in the greenhouse using a field isolate in the fall season in 2012 at MHCREC, Mills River, NC. A field isolate was used to inoculate the 7 -week-old plants at $10^{9}$ sporangia $/ \mathrm{mL}$. Score is the average of six plants scored at the scale of 0 to 5 , where $0=$ no disease, and $5=$ plant completely covered with the disease, planted in two replications. NS $=$ nonsignificant.

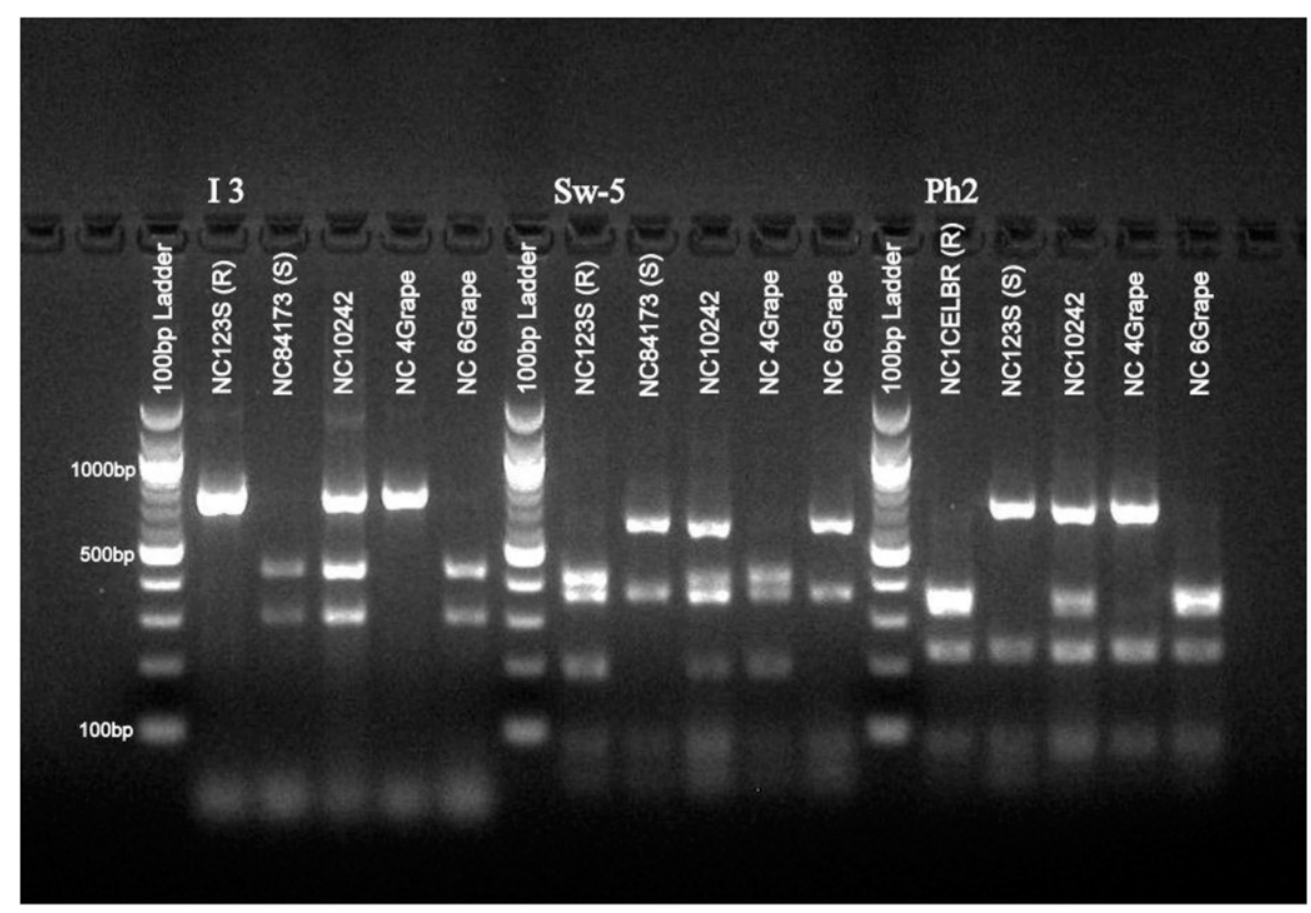

Fig. 2. Molecular screening of 'Mountain Honey' (NC10242) for fusarium wilt race 3 resistance conferred by the I-3 gene, Tomato spotted wilt virus resistance conferred by the $S w-5$ gene, and late blight resistance conferred by the $P h-2$ gene. Molecular markers associated with $I-3, S w-5$, and $P h-2$ were TG217, NCSw011 (Panthee and Ibrahem, 2013), and NCLB-6395-6, respectively, were all cleaved amplified polymorphic sequence (CAPS) type. The genotyping revealed that 'Mountain Honey' was heterozygous for $I-3, S w-5$, and $P h-2$ genes, whereas NC 4 grape was in homozygous condition for $I-3$ and $S w-5$ genes, and NC 6 grape was in homozygous condition for the $P h-2$ gene. In this experiment, NC 1CELBR was used as a resistant control for late blight and NC123S was used as a resistant control for fusarium wilt race 3 and Tomato spotted wilt virus resistance control, whereas NC84173 was used as susceptible control for $I-3$ and $S w$-5. A DNA ladder is used to separate the marker analysis associated with different genes.

\section{Availability}

We plan to license 'Mountain Honey' to a private seed company on an exclusive basis for seed production and sales. It is expected that commercial seed will be available in 2015. Distribution of seed of NC 6 grape to other breeders requires a signed material transfer agreement, which can be downloaded at the following website address: $<$ http:// www.ces.ncsu.edu/fletcher/programs/ tomato/releases/tomato-seed-production-andlicense-agreement.pdf $>$. Small trial samples of 'Mountain Honey' are available from D.R. Panthee (dilip_panthee@ncsu.edu), MHCREC, 455 Research Drive, Mills River, NC 28759.

\section{Literature Cited}

Gardner, R.G. and D.R. Panthee. 2010. Grape tomato breeding lines: NC 1 Grape, NC 2 Grape, and NC 3 Grape. HortScience 45: $1887-1888$
Panthee, D.R. and R.G. Gardner. 2013. 'Mountain Vineyard' hybrid grape tomato and its parents: NC 4 Grape and NC 5 Grape tomato breeding lines. HortScience 48:1189-1191.

Panthee, D.R. and R. Ibrahem. 2013. New molecular markers associated with the $S w-5$ gene conferring resistance to Tomato spotted wilt virus in tomato. J. Hort. Sci. Biotechnol. 88:129-134.

SAS Institute Inc. 2007. The SAS System, version 9.1 .3 for Windows. SAS Institute, Cary, NC. 